\title{
ARAH PENGATURAN UNDANG-UNDANG NOMOR 40 TAHUN 2007 TENTANG PERSEROAN TERBATAS DALAM MENGHADAPI ERA GLOBAL
}

(Regulation for the direction in which the Law Number 40 of 2007 with respect to the Limited Liability Company to be dealt with in the era of Globalization)

\author{
Herlien Budiono \\ Fakultas Hukum Universitas Parahyangan Bandung \\ Jalan Ciumbuleuit 94, Bandung
}

Naskah diterima: 07 Mei 2012; revisi: 02 Juli 2012; disetujui: 11 Juli 2012

\begin{abstract}
Abstrak
Undang-Undang Perseroan Terbatas (UUPT) merupakan salah satu pilar yang memberikan landasan bagi dunia usaha dan perekonomian nasional, dalam menghadapi perkembangan perekonomian dunia di era globalisasi. Meski telah ada berbagai penyempurnaan sejak tahun 2007, tetapi masih terdapat beberapa permasalahan terkait dengan identitas Perseroan Terbatas (PT) sebagai sebuah badan hukum, serta permasalahan lain terkait dengan proses pendiriannya. Dengan menggunakan pendekatan normatif terlihat bahwa meski PT sebagai sebuah badan hukum disebutkan secara jelas dalam Pasal 1 angka 1 UUPT tetapi tidak dijelaskan apa yang dimaksudkan dengan badan hukum. Dengan begitu maka identitasnya lebih banyak ditentukan secara doktrinal lewat berbagai teori. Sedangkan permasalahan terkait pendirian PT didekati dengan menggunakan metode sosio hukum untuk menjelaskan mengenai unsur perjanjian yang masih berpolemik untuk dipenuhi. Begitu juga dengan jumlah pendiri PT, proses pengesahan, penyetoran modal dan jenis mata uang, keputusan di luar Rapat Umum Pemegang Saham (RUPS), serta sarana pendukungnya. Untuk itu disarankan perlunya sinkronisasi yang bersifat teoritis bagi penyempurnaan atas beberapa kelemahan UU PT yang ada saat ini, di samping pembenahan di tingkat pelaksanaan yang masih terasa birokratis.
\end{abstract}

Kata Kunci: tanggung gugat, globalisasi, perseroan terbatas

\begin{abstract}
A Limited Liability Company Act is one of the pillars that provide the foundation for the business world and national economy, in the face of world economic developments in the globalization era. Although there have been many improvements since 2007, but still there are some problems related to the identity of the Limited Liability Company (PT) as a legal entity, as well as other issues related to the establishment of a PT. By using the normative approach is seen that although the Limited Liability Company (PT) as a legal entity is clearly stated in Article 1 number 1 but did not explain what is meant by a legal entity. That way, the identity is determined more doctrinally through various theories. While the problems related to the establishment of a PT approximated using socio-legal methods to explain the elements of the agreement are still debated to be met. So is the number of the founder of the PT number, the process of ratification, the deposit of capital and types of currency, a decision outside the General Meeting of Shareholders, as well as support facilities. It is recommended the need for synchronization of a theoretical nature for the improvement of some weaknesses of existing PT laws today, in addition to improvements in the implementation of which was are still bureaucratic.
\end{abstract}

Keywords: liability, globalization, Limited Liability Company 


\section{A. Pendahuluan ${ }^{1}$}

Perekonomian nasional diselenggarakan berdasar atas demokrasi ekonomi dengan prinsip kebersamaan, efisiensi berkeadilan, berkelanjutan, berwawasan lingkungan, kemandirian, serta dengan menjaga keseimbangan kemajuan dan kesatuan ekonomi nasional, demikian bunyi salah satu konsideran dari Undang-Undang Nomor 40 Tahun 2007 tentang Perseroan Terbatas (UUPT). Untuk meningkatkan pembangunan perekonomian nasional, maka UUPT merupakan salah satu pilar yang telah memberikan landasan bagi dunia usaha dalam menghadapi perkembangan perekonomian dunia dan kemajuan ilmu pengetahuan dan teknologi di era globalisasi ${ }^{2}$ pada masa mendatang.

Meningkatnya tuntutan masyarakat akan layanan yang cepat, kepastian hukum serta tuntutan akan pengembangan dunia usaha mendorong kebutuhan untuk dirumuskannya beberapa pengaturan mengenai perseroan terbatas yang lebih dapat menampung iklim investasi dan dunia perdagangan. Walaupun UUPT telah mengakomodasi hal-hal yang signifikan berkaitan dengan hakikat perseroan tetapi perlu kiranya meninjau beberapa hal berkaitan dengan UUPT yang dapat lebih menampung aspirasi dunia perdagangan dan perubahan yang terjadi khususnya dalam menghadapi era ruang lingkup dunia.

\section{B. Permasalahan}

1. Bagaimanakah identitas Perseroan Terbatas (PT) sebagai sebuah badan hukum, dalam substansi UUPT yang ada saat ini?

2. Permasalahan apakah yang ada dalam pembentukan PT terkait keberadaan UUPT yang berlaku saat ini?

\section{Metode Penelitian}

Berdasarkan identifikasi masalah sebagaimana diuraikan di atas, maka tulisan ini masuk dalam penelitian hukum yang normatif dengan studi kepustakaan. Untuk itu tulisan ini mempergunakan metode penelitian normatif. ${ }^{3}$ Namun demikian tetap akan menggunakan data penelitian empiris ${ }^{4}$ sebagai pendukung. Dengan demikian pokok permasalahan diteliti secara yuridis normatif.

\footnotetext{
Tulisan ini diolah kembali dari makalah yang Penulis sampaikan pada "Seminar Tentang Problematika dan Perspektif Perseroan Terbatas di Indonesia", yang diselenggarakan oleh Badan Pembinaan Hukum Nasional, di Semarang 6 Juni 2012.

2 Globalisasi = Proses masuknya ke ruang lingkup dunia, Kamus Besar Bahasa Indonesia, (Jakarta: Balai Pustaka, 2005), hlm. 366.

3 Soerjono Soekanto dan Sri Mamuji, Penelitian Hukum Normatif, Suatu Tinjauan Singkat, (Jakarta: CV. Rajawali, 1990), hlm. 15. Penelitian normatif adalah penelitian yang dilakukan dengan cara meneliti bahan pustaka atau data sekunder belaka. Pemikiran normatif didasarkan pada penelitian yang mencakup (1) asas-asas hukum, (2) sistematik hukum, (3) taraf sinkronisasi vertikal dan horisontal, (4) perbandingan hukum, (5) sejarah hukum. Lebih jauh tentang ini lihat Soerjono Soekanto dan Sri Mamudji, Penelitian Hukum Normatif: Suatu Tinjauan Singkat, edisi 1, cet.v, (Jakarta: PT Raja Grafindo Persada, 2001), hlm. 13-14. Lihat juga Soerjono Soekanto dan Sri Mamudji, Peranan dan Penggunaan Perpustakaan di Dalam Penelitian Hukum, (Jakarta: Pusat Dokumentasi Hukum Fakultas Hukum Universitas Indonesia, 1979), hlm. 15.

4 Penelitian empiris adalah penelitian yang dilakukan dengan cara meneliti data-data primer, yaitu data yang diperoleh langsung dari masyarakat. Pemikiran empiris ini disebut juga pemikiran sosiologis. Lebih jauh tentang ini lihat Soerjono Soekanto dan Sri Mamudji, ibid.
} 
Tulisan ini juga menggunakan pendekatan sosio hukum, dengan maksud ingin melihat lebih jauh daripada sekedar pendekatan doktrinal, sehingga memiliki perspektif lebih luas dengan melihat hukum dalam hubungannya dengan sistem sosial, politik, dan ekonomi masyarakat. ${ }^{5}$

\section{Pembahasan}

\section{Perseroan Terbatas Sebagai Badan Hukum}

Jika beberapa orang secara bersama-sama bermaksud untuk mencapai tujuan yang sama, akan terdapat dua kemungkinan, yakni pertama terjadi di antara mereka suatu kerja sama, hubungan dan kepentingan timbal balik saling mengikat. Kemungkinan yang ke dua adalah terjadi suatu kesatuan dimana hubungan diantara mereka terhadap pihak ke tiga bukan merupakan tindakan masing-masing melainkan tindakan dari satu kesatuan sedangkan hubungan di antara mereka bukan hubungan satu terhadap yang lain, melainkan merupakan hubungan dengan kesatuannya. Hubungan hukum yang disebutkan terakhir dikenal sebagai badan hukum.

Subyek hukum dan badan hukum merupakan istilah teknis yuridis yakni sebagai pendukung hak dan kewajiban di bidang hukum. Perseroan
Terbatas (PT) merupakan salah satu badan hukum yang diatur di dalam UUPT. Di dalam UUPT tidak dijelaskan apa yang dimaksudkan dengan badan hukum, walaupun Pasal 1 angka 1 UUPT menyebutkan bahwa:

"Perseroan Terbatas, yang selanjutnya disebut Perseroan, adalah badan hukum (...)";

demikian pula Pasal 7 ayat (4) menyebutkan kapan perseroan memperoleh status badan hukum yakni pada tanggal diterbitkannya Keputusan Menteri Hukum dan Hak Asasi Manusia.

Badan hukum dapat terjadi karena undang-undang menyatakannya dengan tegas sebagaimana halnya Pasal 1 angka 1 UUPT, tetapi dapat pula diakui sebagai badan hukum karena adanya ciri-ciri tertentu. Kitab UndangUndang Hukum Dagang tidak pernah secara tegas menyatakan apa yang dimaksudkan dengan badan hukum ${ }^{6}$. Yayasan adalah badan hukum yang dinyatakan dengan tegas oleh Pasal 1 angka 1 Undang-Undang Nomor 16 Tahun 2001 tentang Yayasan jo. Undang-Undang Nomor 28 Tahun 2004 tentang Perubahan Atas Undang-Undang Nomor 16 Tahun 2001 tentang Yayasan.

Teori-teori mengenai badan hukum ${ }^{7}$ mencoba untuk menerangkan gejala hukum yakni

5 Reformasi Hukum di Indonesia, Hasil Studi Perkembangan Hukum, Proyek Bank Dunia (Jakarta: Cyberconsult, 1999) hlm. 153.

6 Di dalam Pasal 40 ayat (2), Pasal 43, dan Pasal 45 ayat (1) Kitab Undang-Undang Hukum Dagang ditemukan unsur-unsur yang cukup untuk menentukan bahwa PT adalah badan hukum. Pada waktu itu pengesahan sebagai badan hukum dilakukan dengan keputusan Menteri Kehakiman (Penetapan Menteri Kehakiman 4 Nopember 1971 Nomor J.A. 5/159/1), sedangkan sejak 1958 hingga 1971 berdasarkan Penetapan Menteri Kehakiman 16 September 1958 Nomor J.A. 5/84/24-TBNRI 752/159), status badan hukum PT baru diperoleh setelah pengesahan Menteri Kehakiman diikuti pendaftaran dan pengumuman di TBNRI, R. Ali Ridho, Hukum Dagang tentang Aspek-Aspek Hukum dalam Asuransi Udara, Asuransi Jiwa dan Perkembangan Perseroan Terbatas, (Jakarta: CV Remadja Karya, 1986), hlm. 306.

Diantaranya teori-teori: teori fictie (Von Savigny, Opzoomer), realiteitstheorie (teori realitas, Von Gierke), theorie van het doelsubject (teori tujuan subjektif, Van der Heyden), collectieve eigendom (teori pemilikan kolektif, Molengraaff), Pitlo Het Nederlands burgerlijk recht Deel 2, Vennootschaps-en rechtspersonenrecht, M.J.G.C.Raaijmakers, vierde, geheel herziene druk, Gouda Quint, Deventer, 2000, hlm. 39. 
adanya suatu organisasi yang mempunyai hak dan kewajiban yang sama dengan orang. Di satu pihak hanya oranglah yang dapat menyatakan kehendaknya tetapi di lain pihak harus diakui adanya suatu bentuk "kerja sama" atau kesatuan yang mempunyai hak dan kewajiban yang terpisah dari hak dan kewajiban orang yang melakukan tindakan hukum atas nama kesatuan tersebut.

Unsur-unsur suatu badan hukum menurut doktrin yang hingga kini diterima adalah:

a) Adanya harta kekayaan yang terpisah;

b) Mempunyai tujuan tertentu;

c) Mempunyai kepentingan sendiri; dan

d) Adanya organisasi yang teratur ${ }^{8}$.

Menurut Asser-Van der Grinten" ${ }^{9}$, teori hukum adalah teori dari gejala hukum yang ada di dalam masyarakat serta di dalam kesadaran orang sehingga teori hukum dapat dan akan mempengaruhi aturan hukum. Hukum positif sadar atau tidak sadar akan tunduk pada teori hukum walaupun teori hukum mempunyai ruang lingkup sendiri tetapi dengan adanya gejala-gejala baru yang timbul, teori hukum akan dapat "memaksa" untuk dilakukan peninjauan atau pembaharuan hukum. Teori hukum memberi bentuk dan mengejawantahkannya ke dalam hukum positif. Singkat kata, teori adalah pertanyaan atas kebenaran, merupakan suatu ajaran dan pengetahuan tetapi bukan suatu perintah atau apa yang harus dilakukan oleh pembentuk undang-undang. Dengan perkataan lain, pembuat undang-undang tidak harus tunduk pada teori hukum.

Diakui atau diterimanya suatu teori hukum akan mempengaruhi pula keputusan yang diambil oleh pembuat undang-undang tatkala menyusun suatu undang-undang. Kriteria mengenai badan hukum perlu ditentukan, misalnya saja melalui menyusun undang-undang tersendiri mengenai badan hukum, ini menjadi sebuah kebutuhan mengingat kemungkinan ikut sertanya badan usaha dari luar negeri sebagai pendiri atau pemegang saham PT sehingga dapat menentukan apakah badan usaha tersebut dapat dikategorikan sebagai badan hukum yang dapat ikut serta di dalam lalu lintas hukum menurut hukum positif kita.

\section{Beberapa Permasalahan Dalam Per- seroan Terbatas}

\section{a. Sifat Pendirian Perseroan Terbatas}

\section{1) pendirian PT berdasarkan perjanjian}

Sesuai dengan bunyi ketentuan Pasal 7 ayat (1) UUPT, suatu PT didirikan oleh 2 (dua) orang atau lebih dengan akta notaris dalam bahasa Indonesia. Diperjelas oleh Pasal 1 angka 1 UUPT, bahwa PT didirikan berdasarkan perjanjian ${ }^{10}$. Di dalam perjanjian pendirian PT sekaligus memuat anggaran dasar dan keterangan-keterangan lain berkaitan dengan pendirian tersebut (Pasal 8 ayat (1) jo. Pasal 15 UUPT). Oleh karena pendirian PT mendasarkan pada perjanjian, maka dengan 
sendirinya semua unsur-unsur perjanjian dan syarat sahnya perjanjian sebagaimana diatur di dalam Buku III KUHPerd, harus pula dipenuhi, dengan kekecualian sebagaimana disebutkan di dalam ketentuan Pasal 7 ayat (7) UUPT.

Ini berarti, bahwa agar suatu perbuatan hukum dapat digolongkan pada perjanjian, unsurunsur perjanjian sebagai berikut harus dipenuhi:

- Adanya kata sepakat dari dua pihak atau lebih;

- Kata sepakat yang tercapai harus bergantung pada para pihak;

- Keinginan atau tujuan para pihak untuk timbulnya akibat hukum;

- Akibat hukum untuk kepentingan pihak yang satu dan atas beban pihak yang lain atau timbal balik; dan

- Dibuat dengan mengindahkan ketentuan perundang-undangan. ${ }^{11}$

Hingga kini, pendirian PT sesuai dengan ketentuan Pasal 1 angka 1 UUPT, digolongkan pada perbuatan hukum berganda ${ }^{12}$ yang merupakan perjanjian. Salah satu unsur, yakni adanya kepentingan serta hubungan antara para pihak yang satu terhadap yang lain atau timbal balik tidak tampak pada perbuatan hukum untuk terbentuknya suatu korporasi (corporatie). Meskipun tidak dipungkiri adanya kesepakatan diantara para pendiri sebelum atau pada saat pendirian - tujuan utama dari pihakpihak adalah terbentuknya korporasi dan bukan suatu hubungan hukum timbal balik diantara para pihak. Ada bentuk hukum (rechtsfiguren) yang tidak memenuhi unsur tersebut sehingga sulit untuk digolongkan pada perbuatan hukum berganda yang merupakan perjanjian. Bentuk hukum semacam itu yang tujuan utamanya adalah terbentuknya korporasi kita kenal, misalnya pendirian perkumpulan ${ }^{13}$ apalagi setelah korporasi tersebut memperoleh status badan hukum.

Pada korporasi seperti maatschap, perseroan firma dan perseroan komanditer, yang tidak digolongkan pada badan hukum, tampak jelas adanya hubungan timbal balik diantara para pesero, baik sebelum, pada saat pendirian maupun selama perseroan berjalan. Janjijanji diantara para pesero seperti kewajiban pemasukan (inbreng), larangan konkurensi, beding-beding meneruskan, mengambil alih, dan klausula berakhirnya perseroan harus dipenuhi oleh para pesero secara timbal balik. Mengingat pada sifat perjanjian (timbal balik) yang harus memenuhi unsur perjanjian dan syarat sahnya perjanjian terbukti pada maatschap, perseroan firma dan perseroan komanditer yang baik pada saat pendirian maupun selama perseroan berjalan, pembuatan akta-aktanya menggunakan bentuk akta pihak bukan akta berita acara (relaas).

Pada korporasi seperti pada perkumpulan dan yayasan yang pendiriannya digolongkan pada tindakan hukum sepihak ${ }^{14}$, akta pendiriannya dibuat dalam bentuk akta pihak (partij) tetapi sejak memperoleh status badan hukum maka berlakulah anggaran dasar dari badan hukum

11 C.Asser-A.S.Hartkamp, Verbintenissenrecht, Algemene Leer der Overeenkomsten, (W.E.J.Tjeenk Willink, Zwolle, 1989), hlm. 9-14.

12 "Tindakan hukum berganda adalah tindakan yang memerlukan kerja sama dari dua pihak atau lebih untuk memunculkan akibat hukum".

13 C.Asser-A.S.Hartkamp, Verbintenissenrecht, Algemene Leer der Overeenkomsten, (W.E.J.Tjeenk Willink, Zwolle, 1989), hlm. 13-14.

14 Tindakan hukum sepihak adalah tindakan yang dilakukan oleh satu pihak saja dan yang menimbulkan, berubah, dan berakhirnya suatu hak. 
tersebut dan keputusan yang diambil tidak dapat digolongkan pada kesepakatan yang tercapai seperti pada perjanjian. Oleh karenanya doktrin menggolongkan sifat tercapainya kata sepakat pada rapat-rapat organ perkumpulan, yayasan demikian pula pada PT, sebagai Gesamtakt ${ }^{15}$, suatu perbuatan hukum yang terjadi karena kerja sama dari beberapa orang (pihak) tetapi tidak dapat digolongkan pada perjanjian. Kesepakatan yang tercapai pada rapat adalah berdasarkan telah terpenuhinya korum kehadiran dan korum keputusanyangtidaktergantungpadakesepakatan dari semua pihak. Lagipula keputusan tersebut tidak berakibat untuk kepentingan yang satu atas beban yang lain atau timbal balik diantara para pihak. Dalam hal ini, karena sifat peristiwa hukum tersebut bukan perjanjian, maka bentuk aktanya adalah akta berita acara (relaas).

\section{2) Pendirian PT sebagai tindakan hukum sepihak}

PT didirikan oleh 2 (dua) orang atau lebih berdasarkan perjanjian dengan akta notaris yang dibuat dalam bahasa Indonesia. Setelah PT memperoleh status badan hukum, maka berlakulah anggaran dasar (dan peraturan perundang-undangan lainnya) sepanjang tidak bertentangan dengan UUPT. Jika pemegang saham menjadi kurang dari 2 (dua) orang, maka dalam jangka waktu paling lama 6 (enam) bulan terhitung sejak keadaan tersebut, pemegang saham wajib mengalihkan sebagian sahamnya kepada orang lain atau PT mengeluarkan saham baru kepada orang lain. Sanksi atas dilampauinya jangka waktu pengalihan sebagian saham kepada orang lain atau dikeluarkannya saham baru kepada orang lain mengakibatkan bahwa pemegang saham bertanggung jawab secara pribadi dan atas permohonan pihak yang berkepentingan, pengadilan negeri dapat membubarkan PT tersebut.

Sebagaimana kita ketahui salah satu ciri dari PT sebagai badan hukum yang diakui oleh doktrin adalah adanya kekayaan yang terpisah antara kekayaan PT dan kekayaan pemegang saham, demikian pula tanggung jawab pemegang saham hanya terbatas pada jumlah saham yang disetorkan (Pasal 3 ayat (1) UUPT). Ketentuan tersebut tidak berlaku apabila terjadi hal yang disebutkan di dalam ayat (2)nya. PT didirikan dengan tujuan untuk terbentuknya badan hukum dengan akibat adanya kekayaan yang terpisah dari pemegang saham serta tanggung jawab yang terbatas.

Oleh karena itu pendirian PT oleh satu orang, dua orang atau lebih tidak menyebabkan tanggung jawabnya menjadi berbeda. Modal PT sebesar Rp. 500.000.000,- (lima ratus juta rupiah) yang akan menjadi jaminan serta tanggung jawab PT terhadap pihak ke tiga tidak akan berbeda apakah saham PT dimiliki oleh satu orang pemegang saham atau dimiliki oleh 100 (seratus) orang pemegang saham. Selain mengenai kekayaan yang terpisah serta tanggung jawab yang terbatas, pendirian PT berdasarkan perjanjian telah tidak memenuhi teori hukum perjanjian, sehingga adalah lebih logis untuk menggolongkan pendirian PT pada tindakan hukum sepihak sebagaimana halnya dengan pendirian perkumpulan dan yayasan. ${ }^{16}$

C.Asser-A.S.Hartkamp, Verbintenissenrecht, Algemene Leer der Overeenkomsten, (W.E.J.Tjeenk Willink, Zwolle, 1989), hlm. 14.

16 Pasal 2:175 ayat 2 NBW: De vennootschap wordt door een of meer personen bij notarieële akte (...). 
Dengan demikian ketentuan mengenai keharusan adanya sekurang-kurangnya 2 (dua) orang pemegang saham setelah PT memperoleh status badan hukum tidak diperlukan lagi. Ancaman sanksi bahwa pemegang harus bertanggung jawab secara pribadi dan atas permohonan pihak yang berkepentingan, pengadilan negeri dapat membubarkan PT tersebut dapat menggangu hubungan hukum antara pihak ke tiga dengan PT yang bersangkutan malahan mungkin dapat merugikan para pihak. Kelanggengan hubungan hukum dan/atau perdagangan antara PT dengan pihak ke tiga perlu dijamin dengan peraturan perundang-undangan. Jikalau ditakutkan bahwa PT sebagai pemilik tunggal saham PT akan menguasai kegiatan usaha di bidang tertentu, dapat ditentukan persyaratan dengan peraturan menteri terkait yang dapat menjamin kepentingan umum. Inipun tidak berbeda dengan keadaan sekarang dimana pemerintah mengeluarkan persyaratan khusus untuk kegiatan usaha tertentu seperti di bidang kedirgantaraan, pertambangan, perbankan dan lain lain.

Di dalam praktik ketentuan pendirian PT berdasarkan perjanjian, demikian pula ketentuan keharusan agar saham-saham PT dimiliki oleh 2 (dua) orang pemegang saham menimbulkan penyelundupan hukum dengan menggunakan perjanjian pura-pura (simulasi) ${ }^{17}$ atau memakai nominee (stroman). PT didirikan oleh A dan B di mana $A$ dengan akta di bawah tangan telah mengalihkan sahamnya kepada $B$ atau dengan cara A mengakui dan menyatakan bahwa saham yang secara formil adalah milikinya sebetulnya adalah milik B. Hal yang sama dilakukan dengan membuat perjanjian pura-pura agar seakanakan PT tetap mempunyai 2 (dua) orang pemegang saham setelah PT memperoleh status badan hukum. Perjanjian simulasi atau menggunakan nominee (stroman) tidak perlu terjadi jika tidak disyaratkan adanya ketentuan yang mengharuskan PT didirikan berdasarkan perjanjian dan keharuskan adanya 2 (dua) orang pemegang saham setelah PT memperoleh status badan hukum.

\section{b. Proses pengesahan PT sebagai badan hukum \\ Di dalam ketentuan Pasal 9, Pasal 10} dan Pasal 11 UUPT telah dirinci tata cara memperoleh Keputusan Menteri Hukum dan Ham mengenai pengesahan badan hukum suatu PT. Jangka waktu pengajuan akta pendirian untuk memperoleh status badan hukum telah ditentukan secara ketat. Dalam hal permohonan untuk memperoleh keputusan menteri mengenai pengesahan tidak diajukan tepat waktu yakni 60 (enam puluh) hari terhitung sejak tanggal akta pendirian ditandatangani akan mengakibatkan akta pendirian menjadi batal sejak lewatnya jangka waktu tersebut dan PT bubar karena hukum dan pemberesan harus dilakukan oleh pendiri. Sebelum PT memperoleh status badan hukum maka perbuatan hukum atas nama PT hanya boleh dilakukan oleh semua anggota Direksi bersama-sama semua pendiri serta semua anggota Dewan Komisaris yang semuanya bertanggung jawab renteng atas perbuatan

17 Suatu perjanjian di mana secara sadar dilakukan suatu perbuatan hukum yang tidak sesuai dengan keadaan sebenarnya atau di mana kemauan (wil) tidak sesuai dengan pernyataan (verklaring), C. Asser-A.S.Hartkamp, Verbintenissenrecht, Algemene Leer der Overeenkomsten, W.E.J. Tjeenk Willink, Zwolle, 1989, hlm. 113; Herlien Budiono, Ajaran Umum Hukum Perjanjian dan Penerapannya di Bidang Kenotariatan, cet. ke-3, (Bandung: P.T. Citra Aditya Bakti, 2011), hlm. 86-91. 
hukum tersebut (Pasal 14 UUPT). Masalah yang timbul dan dapat merugikan pihak ke tiga adalah jika PT telah mengadakan perjanjian dengan pihak ke tiga tetapi karena keterlambatan permohonan pengesahan mengakibatkan PT bubar karena hukum. Walaupun adanya tanggung jawab secara tanggung renteng diantara Direksi, Dewan Komisaris dan pendiri tetapi dengan bubarnya PT memerlukan penyelesaian tersendiri. Bukankah pihak ke tiga yang beritikad baik harus dilindungi. Lain halnya jika mengikuti tata cara diperolehnya terlebih dahulu keterangan tidak keberatan dari Menteri Hukum dan Ham sebelum akta pendirian PT ditandatangani dihadapan notaris ${ }^{18}$, tentunya dengan mengirimkan konsep akta pendiriannya terlebih dahulu kepada Menteri Hukum dan HAM. PT memperoleh status badan hukum dengan ditandatanganinya akta pendirian PT dalam jangka waktu yang ditentukan. Dengan cara demikian dapat dihindari kerugian yang diderita oleh pihak ke tiga karena telah melakukan perjanjian dengan PT yang bubar karena terlambat pengajuan permohonan pengesahannya. Cara yang sama dapat pula diberlakukan terhadap perubahan anggaran dasar yang memerlukan persetujuan dari Menteri Hukum dan Ham sebagaimana dimaksud dalam Pasal 21 ayat (2) UUPT.

\section{c. Penyetoran atas modal saham}

PT adalah badan hukum yang merupakan persekutuan modal guna menunjang kegiatan usaha dengan modal dasar yang seluruhnya terbagi dalam saham. Setiap pendiri PT wajib mengambil bagian saham pada saat PT didirikan. Penyetoran atas modal saham dapat dilakukan dalam bentuk uang dan/atau dalam bentuk lainnya. Mengingat dalam rangka menghadapi era global dapat kiranya dimungkinkan penyetoran atas modal saham dilakukan dalam bentuk mata uang asing, asalkan di dalam anggaran dasarnya dimuat ketentuan mengenai hal tersebut. Penyetoran dengan menggunakan mata uang asing harus dilakukan dalam jumlah yang senilai dengan rupiah dan dengan ketentuan bahwa mata uang asing tersebut dapat dikonversi dengan rupiah. Penentuan dari kurs ditetapkan pada hari penyetoran dan jika telah dilakukan lebih lama dari sebulan (atau jangka waktu lain), maka kurs ditetapkan pada tanggal pendirian PT. Sebagai contoh $^{19}$ :

1) penyetoran atas modal saham dapat dilakukan dalam bentuk uang dan/atau dalam bentuk lainnya;

2) Sebelum atau pada saat pendirian perseroan, penyetoran atas modal saham dapat dilakukan dalam mata uang asing yang hanya dapat dilakukan jika di dalam akta pendirian perseroan dinyatakan diperbolehkan bahwa penyetoran atas modal saham dapat dilakukan dalam mata uang asing; penyetoran atas modal saham dalam mata uang asing atas pengeluaran saham lebih lanjut harus disetujui oleh perseroan;

3) Dengan penyetoran atas modal saham dalam mata uang berarti telah dipenuhi kewajiban penyetoran atas modal saham untuk jumlah

18 Di Nederland telah memakai sistem pengesahan PT dengan mengeluarkan terlebih dahulu suatu surat tidak keberatan (een verklaring van geen bezwaar) sebelum akta pendirian PT ditandatangani yakni notaris mengirimkan terlebih dahulu konsep akta pendiriannya kepada menteri kehakiman. Sejak Wet 7 juli 2010 no 280 telah diubah Pasal 4 ayat pertama buku 2 NBW, yakni dihilangkannya kalimat "of een verklaring van geen bezwaar" (atau keterangan tidak keberatan) yang berarti PT memperoleh status badan hukum sejak ditandatanganinya akta pendirian dihadapan notaris tanpa diperlukan keterangan tidak keberatan dari menteri kehakiman.

19 Mengambil contoh dari Pasal 2:191a NBW. 
yang senilai dengan jumlah yang harus disetor dan dapat ditukarkan dalam mata uang di Indonesia. Kurs atas mata uang asing yang menentukan adalah pada hari penyetoran dilakukan dan jika penyetoran tersebut dilakukan lebih lama dari 1 (satu) bulan sebelum pendirian perseroan maka kurs tersebut adalah pada hari perseroan didirikan.

Transaksi dalam mata uang asing sudah lazim di dalam dunia perdagangan internasional sehingga UUPT seyogyanya dapat menampung kemungkinan masalah penyetoran dalam bentuk mata uang asing. Dipaksakannya penyetoran dalam bentuk rupiah dalam konstelasi era global akan memberi kesan kurang aspiratif serta dapat merugikan pihak asing sebagai pemegang saham karena berarti harus dikonversikan mata uang yang dimiliki (calon) pemegang saham, sehingga akan ada perbedaan pada kurs beli/ jual.

\section{d. Keputusan pemegang saham di luar RUPS}

Setelah PT memperoleh status badan hukum, maka semua keputusan yang diambil oleh para pemegang saham pada umumnya adalah melalui RUPS, RUPS merupakan organ PT yang mempunyai wewenang yang tidak diberikan kepada Direksi atau Dewan Komisaris dalam batas yang ditentukan dalam UUPT dan/atau anggaran dasar (Pasal 75 ayat (1) UUPT). Jikalau suatu PT mempunyai pemegang saham saham yang relatif sedikit, maka lebih mudah mengumpulkan mereka dibandingkan dengan PT yang pemegang sahamnya banyak baik untuk rapat yang risalahnya dibuat secara di bawah tangan atau risalah rapatnya yang dihadiri dan dibuat oleh seorang notaris. UUPT sendiri telah cukup fleksibel di dalam menghadapi kemungkinan sulitnya mengumpulkan para pemegang saham pada satu saat dan pada suatu tempat (rapat). Oleh UUPT telah ditampung dengan baik masalah berkaitan dengan dilakukannya RUPS dengan menggunakan lembaga perwakilan melalui surat kuasa (Pasal 85 ayat(1)UUPT), dimungkinkannyapenyelenggaraan RUPS melalui media telekonferensi, video konferensi atau sarana elektronik lainnya (Pasal 77 UUPT). Dengan kemajuan di bidang teknologi informasi, UUPT telah pula memanfaatkan sarana tersebut yakni dalam rangka pengajuan permohonan pengesahan, perubahan anggaran dasar PT melalui jasa teknologi informasi sistem administrasi badan hukum secara elektronik (Pasal ( UUPT).

Selain pengambilan keputusan para pemegang saham melalui RUPS, dikenal pula pengambilan keputusan yang mengikat di luar RUPS asalkan semua pemegang saham dengan hak suara menyetujui secara tertulis dengan menandatangani usul yang bersangkutan (pasal 91 UUPT). Dalam rangka menghadapi era global diusulkan agar para pemegang saham selain memberikan persetujuan secara menandatangani usul yang bersangkutan dapat pula dilakukan secara elektronik. Contoh ${ }^{20}$ :

(1) Pemegang saham dapat juga mengambil keputusan yang mengikat di luar RUPS dengan syarat semua pemegang saham dengan hak suara menyetujui secara tertulis dengan menandatangani usul yang bersangkutan;

(2) Kecuali anggaran dasar menentukan lain pemberian persetujuan untuk pengambilan

20 Mengambil contoh dari usulan perubahan atas Pasal 2:238 NBW kepada Tweede Kamer der Staten-Generaal, Vergader jaar 2009-2010, 32426, nr.2, ISSN 0921-7371. s'Gravenhage 2010. 
keputusan sebagaimana dimaksud pada ayat (1) dapat dilakukan secara elektronik. Cara pengambilan keputusan secara elektronik diberitahukan terlebih dahulu kepada Direksi dan Dewan Komisaris yang diberi kesempatan untuk memberikan pendapat dan nasihat mereka mengenai cara pengambilan keputusan secara elektronik tersebut.

\section{e. Sarana pendukung}

Sarana pendukung yang dimaksud dalam tulisan ini tidak langsung berkaitan dengan UUPT tetapi erat berhubungan dengan lancarnya pelaksanaan UUPT didalam praktik. Sebagaimana diketahui, notaris berwenang membuat akta otentik mengenai semua perbuatan, perjanjian, dan ketetapan yang diharuskan oleh peraturan perundang-undangan dan/atau yang dikehendaki olehyang berkepentingan untuk dinyatakan dalam akta otentik. Di dalam melaksanakan jabatannya, notaris terikat pada tempat kedudukan di daerah kabupaten atau kota walaupun notaris mempunyai wilayah jabatan meliputi seluruh wilayah provinsi dari tempat kedudukannya (Pasal 18 UUJN $^{21}$ ). Ini berarti, bahwa siapapun yang membutuhkan bantuan notaris dan datang ke kantor notaris untuk minta bantuan berkaitan dengan pembuatan akta notaris, maka notaris wajib memberikan bantuannya, sepanjang pembuatan akta tersebut tidak dilarang baik oleh UUJN maupun perundang-undangan lainnya. Jika para pendiri PT datang kepada notaris di kota A untuk mendirikan PT dengan tempat kedudukan di kota B, maka akta pendirian PT dapat dilakukan oleh notaris di kota A. Adanya penolakan yang terjadi atas pengeluaran izin usaha karena akta pendirian perseroan tidak dibuat dihadapan notaris ditempat kedudukan perseroan tersebut atau karena direktur perseroan tidak mempunyai kartu tanda penduduk ditempat kedudukan perseroan. Mudah-mudahan tidak akan terjadi penolakan pengeluaran izin usaha PT di kota B karena akta pendirian PT-nya dibuat oleh notaris di kota A.

Singkat kata, di beberapa kota/daerah ada ketidak sinkronan antara UUPT dengan peraturan daerah kota/kabupaten dan/atau instansi terkait dengan PT yang dapat menghambat lancarnya iklim investasi khususnya menghadapi era global. Alangkah baiknya jika nanti akan diberlakukan perubahan atas UUPT dilakukan pula penyuluhan kepada instansi terkait sehingga PT tidak mengalami hambatan di dalam menjalankan kegiatannya. Selain kurangnya pengetahuan yang up-to-date dari pejabat dari instansi yang bersangkutan, juga perlu dikurangi birokrasi yang masih dirasakan oleh para pengusaha.

\section{E. Penutup}

\section{Kesimpulan}

Perseroan Terbatas (PT) sebagai sebuah badan hukum disebutkan secara jelas dalam Pasal 1 angka 1 UUPT yang menyebutkan bahwa: "Perseroan Terbatas adalah badan hukum". Meski demikian, di dalam UUPT tidak dijelaskan apa yang dimaksudkan dengan badan hukum. Badan hukum dapat terjadi karena undang-undang menyatakannya dengan tegas sebagaimana halnya Pasal 1 angka 1 UUPT, tetapi dapat pula diakui sebagai badan hukum karena adanya ciri-ciri tertentu. Kitab UndangUndang Hukum Dagang tidak pernah secara tegas menyatakan apa yang dimaksudkan

21 UUJN = Undang-Undang Republik Indonesia Nomor 30 Tahun 2004 tentang Jabatan Notaris. 
dengan badan hukum. Teori-teori mengenai badan hukum mencoba untuk menerangkan gejala hukum yakni adanya suatu organisasi yang mempunyai hak dan kewajiban yang sama dengan orang. Di satu pihak hanya oranglah yang dapat menyatakan kehendaknya tetapi di lain pihak harus diakui adanya suatu bentuk "kerja sama" atau kesatuan yang mempunyai hak dan kewajiban yang terpisah dari hak dan kewajiban orang yang melakukan tindakan hukum atas nama kesatuan tersebut. Unsurunsur suatu badan hukum menurut doktrin yang hingga kini diterima adalah: Adanya harta kekayaan yang terpisah; Mempunyai tujuan tertentu; Mempunyai kepentingan sendiri; dan Adanya organisasi yang teratur.

Permasalahan yang ada dalam pembentukan PT terkait keberadaan UUPT yang berlaku saat ini antara lain adalah sifat pendirian PT yang pada dasarnya adalah perjanjian, namun salah satu unsur perjanjian tidak tampak pada perbuatan hukum untuk terbentuknya suatu korporasi (corporatie). Permasalahan lain yang timbul akibat dasar pendirian PT adalah perjanjian, maka PT didirikan oleh 2 orang atau lebih, sehingga adanya keharusan minimal 2 (dua) orang pemegang saham, namun dengan adanya kekayaan yang terpisah dari pemegang saham serta tanggung jawab yang terbatas, maka syarat ini seharusnya tidak diperlukan lagi. Selain itu, apabila terjadi keterlambatan permohonan pengesahan, maka PT bubar karena hukum, sehingga timbul masalah, yaitu kerugian pada pihak ke tiga yang telah mengadakan perjanjian dengan PT. Fakta di lapangan sering pula timbul masalah terkait dengan adanya penolakan yang terjadi atas pengeluaran izin usaha karena akta pendirian perseroan tidak dibuat dihadapan notaris ditempat kedudukan perseroan tersebut atau karena direktur perseroan tidak mempunyai kartu tanda penduduk ditempat kedudukan perseroan, selain itu adanya kewajiban penyetoran dalam bentuk rupiah dalam konstelasi era global akan memberi kesan kurang aspiratif serta dapat merugikan pihak asing sebagai pemegang saham.

\section{Saran}

Perlu dilakukan penelitian hukum mengenai beberapa permasalahan PT secara empirik (yang bersifat socio-legal) yang melihat hukum bukan semata-mata sebagai norma hukum positif saja, tetapi sebagai hukum yang hidup.

Oleh karena itu antara lain perlu dilakukan perubahan atas UUPT sebagai penyempurnaan atas beberapa kelemahan yang ada saat ini; perlu sinkronisasi antara UUPT dengan peraturan daerah kota/kabupaten dan/atau instansi terkait dengan PT yang dapat menghambat lancarnya iklim investasi khususnya menghadapi era global; perlu meng-up-to-date pengetahuan tentang PT dari pejabat instansi yang bersangkutan; perlu dikurangi birokrasi yang masih dirasakan oleh para pengusaha.

Jika nanti akan diberlakukan perubahan atas UUPT, maka perlu penyuluhan kepada instansi terkait sehingga PT tidak mengalami hambatan di dalam menjalankan kegiatannya.

\section{DAFTAR PUSTAKA}

\section{Buku}

C. Asser-Van der Grinten, Vertegenwoordiging en Rechtspersoon, De Rechtspersoon, vierde druk, (W.E.J.Tjeenk Willink, Zwolle, 1976).

C. Asser-A.S.Hartkamp 4-II, Verbintenissenrecht, Algemene Leer der Overeenkomsten, tiende druk, (W.E.J.Tjeenk Willink, Zwolle), 1989.

Budiono, Herlien, Ajaran Umum Hukum Perjanjian dan Penerapannya di Bidang Kenotariatan, cet. ke-3, (Bandung: P.T. Citra Aditya Bakti, 2011).

Kamus Besar Bahasa Indonesia, (Jakarta: Balai Pustaka, 2005) 
Pitlo Het Nederlands burgerlijk recht Deel 2, Vennootschaps-en rechtspersonenrecht, M.J.G.C.Raaijmakers, vierde, geheel herziene druk, Gouda Quint, Deventer, 2000.

Ridho, R. Ali, Hukum Dagang tentang Aspek-Aspek Hukum dalam Asuransi Udara, Asuransi Jiwa dan Perkembangan Perseroan Terbatas, (Jakarta: CV Remadja Karya, 1986).

Reformasi Hukum di Indonesia, Hasil Studi Perkembangan Hukum, Proyek Bank Dunia (Jakarta: Cyberconsult, 1999).
Soekanto, Soerjono dan Sri Mamuji, Penelitian Hukum Normatif, Suatu Tinjauan Singkat, (Jakarta: CV. Rajawali, 1990).

Soekanto, Soerjono dan Sri Mamudji, Peranan dan Penggunaan Perpustakaan di Dalam Penelitian Hukum, (Jakarta: Pusat Dokumentasi Hukum Fakultas Hukum Universitas Indonesia, 1979). 